Original Research

\title{
Estimating Met-Ocean Parameters during a Tropical Cyclone for Marine Science and Engineering
}

Shih-Ang Hsu *

1. Coastal Studies Institute; E-Mail: sahsu@lsu.edu

2. Louisiana State University, Baton Rouge, LA 70803, USA

* Correspondence: Shih-Ang Hsu; E-Mail: sahsu@lsu.edu

Academic Editor: Aritra Ghosh

Special Issue: Progress of Wind Energy Technology and Its Maintenance

Journal of Energy and Power Technology

2021, volume 3, issue 2

doi:10.21926/jept.2102025
Received: April 16, 2021

Accepted: June 01, 2021

Published: June 16, 2021

\begin{abstract}
During a tropical cyclone (TC) worldwide, the Regional and Mesoscale Meteorological Branch (RAMMB) of NOAA/NESDIS (http://rammb.cira.colostate.edu/) issues real-time TC surface wind analyses. The purpose of this article is to provide value-added estimations of several meteorological and oceanographic (met-ocean) parameters including overwater friction velocity and turbulence intensity, variation of the wind speed with height, significant wave height, peak or dominant wave period, wind-driven currents and wind-stress tides. Since these proposed value-added parameters are also validated by other independent methods available from the literature, these met-ocean parameters may be used for marine science and engineering including offshore energy (such as oil, gas and wind power) research, development, operation and maintenance.
\end{abstract}

\section{Keywords}

Tropical cyclones; RAMMB products; friction velocity; significant wave height; wind-driven currents; wind-stress tides

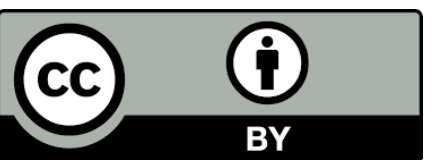

(C) 2021 by the author. This is an open access article distributed under the conditions of the Creative Commons by Attribution License, which permits unrestricted use, distribution, and reproduction in any medium or format, provided the original work is correctly cited. 


\section{Introduction}

This study is motivated by an article by Bancroft ([1] available online at http://www.vos.noaa.gov/MWL/201604/northpacific.shtml\#contents) who stated that, as shown in Figure 1, at 1200 UTC on the 4th of August 2015, Soudelor was a super typhoon near 19N 137E with sustained winds 140 knots $\left(72 \mathrm{~m} \mathrm{~s}^{-1}\right)$ and it is just a coincidence that we have a Jason-2 altimeter pass through the eye wall of Soudelor. Note the highest significant wave height of 90.55 feet (or $27.6 \mathrm{~m}$ ) in the northwest eye wall. During this period, the Regional and Mesoscale Meteorological Branch (RAMMB) of NOAA/NESDIS (http://rammb.cira.colostate.edu/) issued a realtime TC surface wind analysis as presented in Figure 2 . Since it is only fortuitous that we have both wind and wave measurements by different satellites at the same time in the same area, a question related to marine meteorology and physical oceanography (met-ocean) is raised that can one estimate the significant wave height from the routinely available RAMMB product during a tropical cyclone worldwide? If so, can this real-time TC surface wind analysis be used to estimate other metocean parameters?

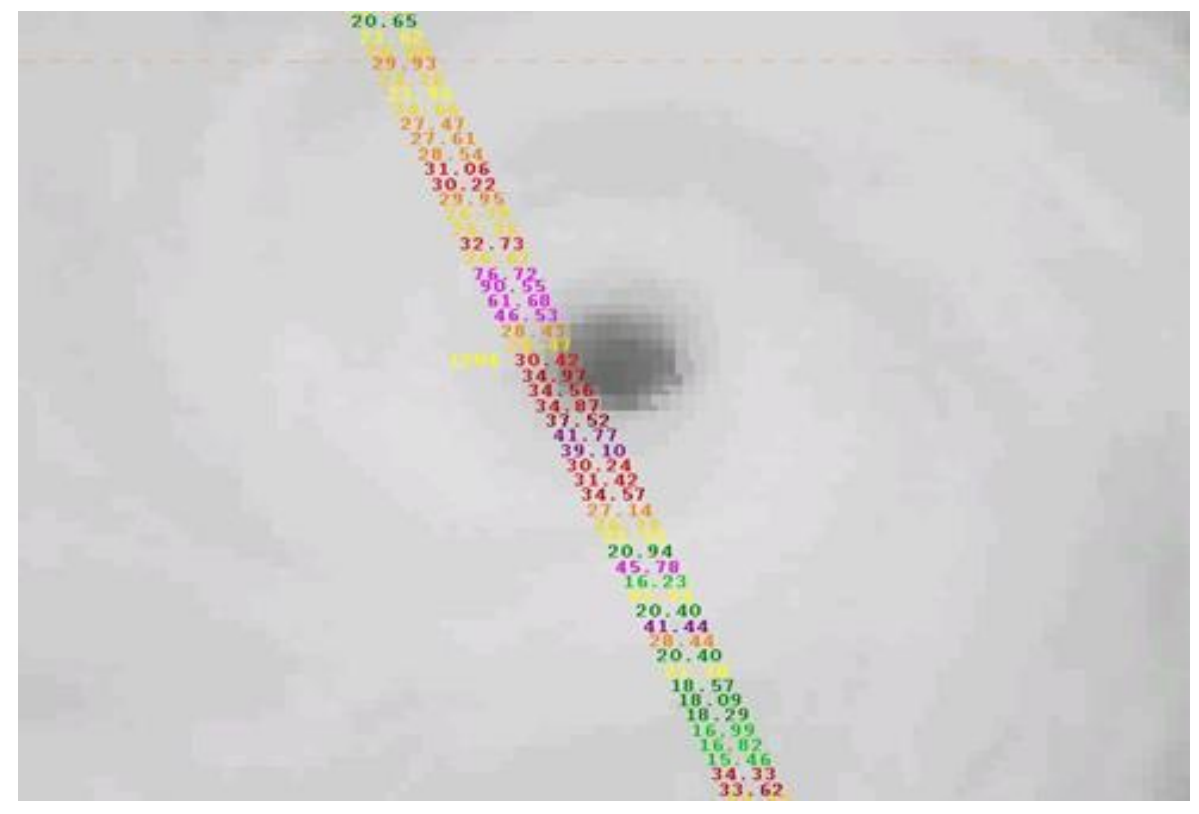

Figure 1 A zoomed-in infrared satellite Image of Super-Typhoon Soudelor valid 1232 UTC August 4, 2015. A Jason -2 altimeter pass appears as a swath of significant wave heights given in feet to two decimal places cutting across the central core of Soudelor [After Bancroft GP [1], for more detail, see http://www.vos.noaa.gov/MWL/201604/northpacific.shtml\#contents)]. 


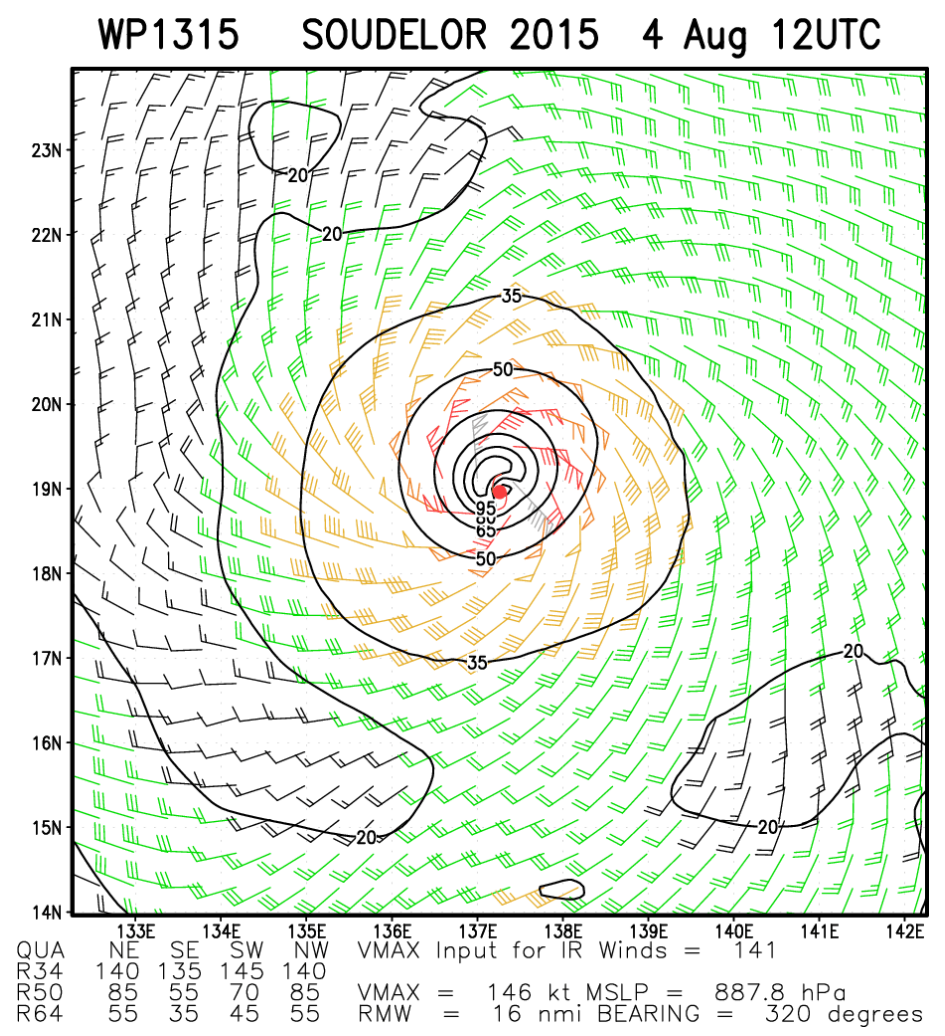

Figure 2 A real-time TC surface wind analysis issued by RAMMB. See https://rammbdata.cira.colostate.edu/tc realtime/image mpsatwnd.asp?product=mpsatwnd\&storm identifier=wp132015\&product filename=2015wp13 mpsatwnd 201508041200 .

During a tropical cyclone (TC), estimation of several met-ocean parameters, e.g., from the air side, wind and friction velocity, and from the ocean side, waves, currents and storm surges, are needed. The reason for the estimation of overwater friction velocity is because it is related to the wind stress which is the forcing parameter for nearly all air-sea interaction processes [2]. An example is shown in Figure 3. During this period, according to [3], an extreme significant wave height, $H_{\mathrm{s}}=23.9 \mathrm{~m}$, was measured near the 110 knots $\left(57 \mathrm{~m} \mathrm{~s}^{-1}\right)$ isotach just offshore of northeastern Taiwan. From the met-ocean viewpoint, was this high $H_{\mathrm{s}}$ value generated by those $57 \mathrm{~m} \mathrm{~s}^{-1}$ winds and what was the wind-driven current associated with this high $H_{s}$ value? Therefore, it is the purpose of this article to estimate these and other related met-ocean parameters. Note that, hereafter, the word "estimation" as used in this study may be applicable interchangeably with a nowcasting (up to 6-hours) near the time such as Figure 2 or hindcasting to reconstruct the met-ocean conditions, e.g., the damage assessment occurred during a TC. 


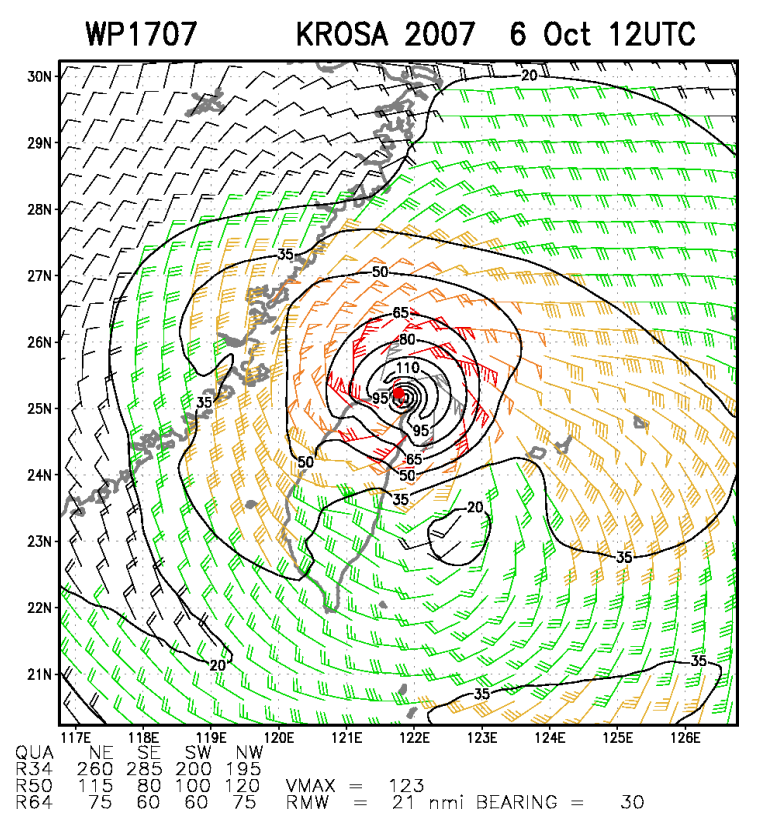

Figure 3 An example of the real-time TC surface wind analysis during Typhoon Krosa in 2007 near Taiwan (see https://rammbdata.cira.colostate.edu/tc realtime/image mpsatwnd.asp?product=mpsatwnd\&storm identifier=wp172007\&product filename=2007wp17 mpsatwnd 200710061200).

\section{Estimating the Wind Speed at $10-\mathrm{m}, \mathrm{U}_{10}$}

According to [4, p.22 and Figure 2.8],

$$
\mathrm{U}_{10}=\mathrm{U}_{10 \text { max }}\left(R_{\text {max }} / r\right)^{0.5}
$$

Here $U_{10}$ is the wind speed at $10-\mathrm{m}$ at the distance, $r$, away from the radius of max wind, $R_{\max }$ and $U_{10 \max }$ is the wind speed at $10-\mathrm{m}$ at $R_{\max }$. A verification of Eq. (1) is presented as follows for Buoy 42056 located in the northwestern Caribbean Sea:

During Hurricane Dean in August 2007, the National Data Buoy Center (see [5] https://www.ndbc.noaa.gov/hurricanes/2007/dean/) provided the measurements needed to validate Eq. (1). From Figures 4, Figure 5 and Figure 6 based on NDBC and Figure 7 on RAMMB's product, we have $U_{10 \max }=114 \mathrm{kts}, R_{\max }=28 \mathrm{~nm}$ and $\mathrm{r}=98.1 \mathrm{~nm}$, the closest point of approach (CPA) (Table 1) between Buoy 42056 and Dean's center (Figure 7).

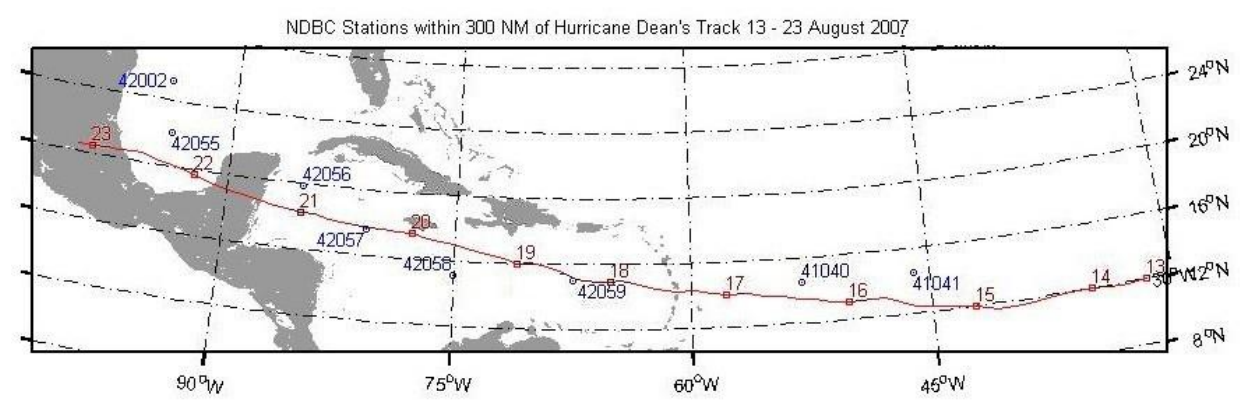

Figure 4 NDBC stations within $300 \mathrm{~nm}$ of Dean's track. Note: Stations 42057 and 42058 were not reporting during this period. 


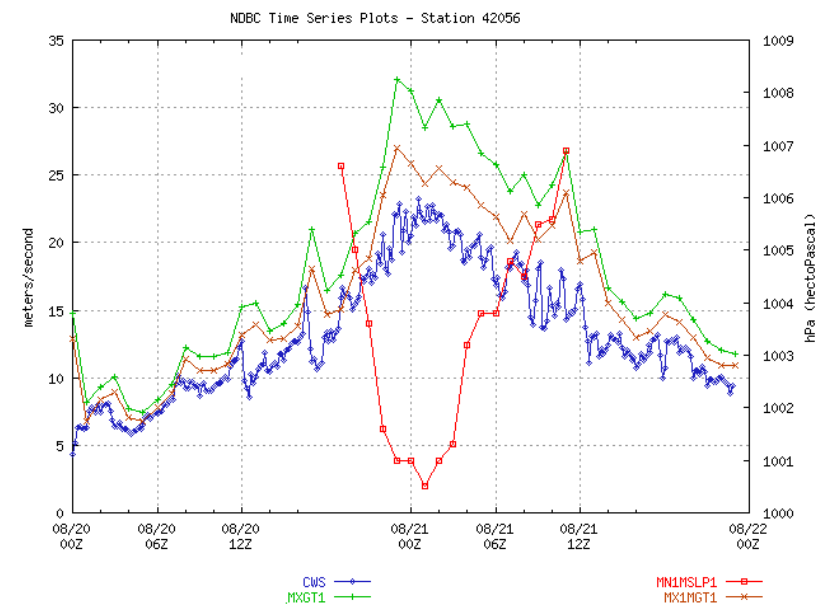

Figure 5 Station 42056, winds (anemometer height 10m) and sea-level pressure.

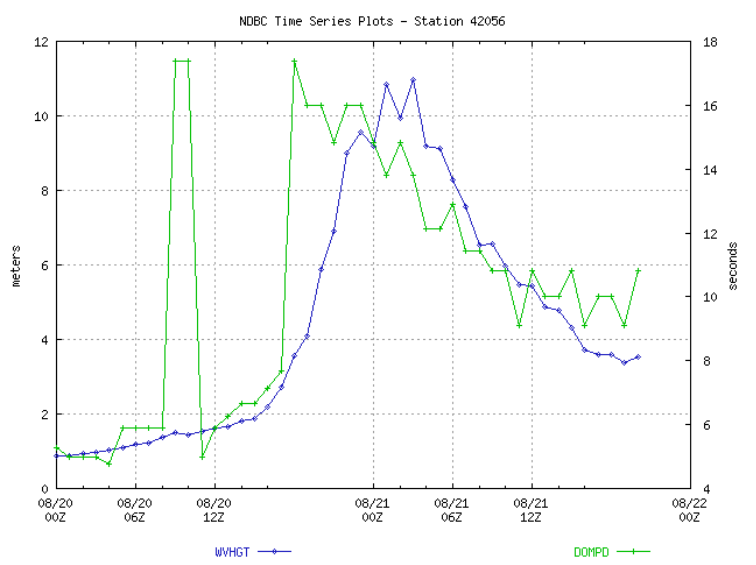

Figure 6 Station 42056: Significant wave height and dominant period.

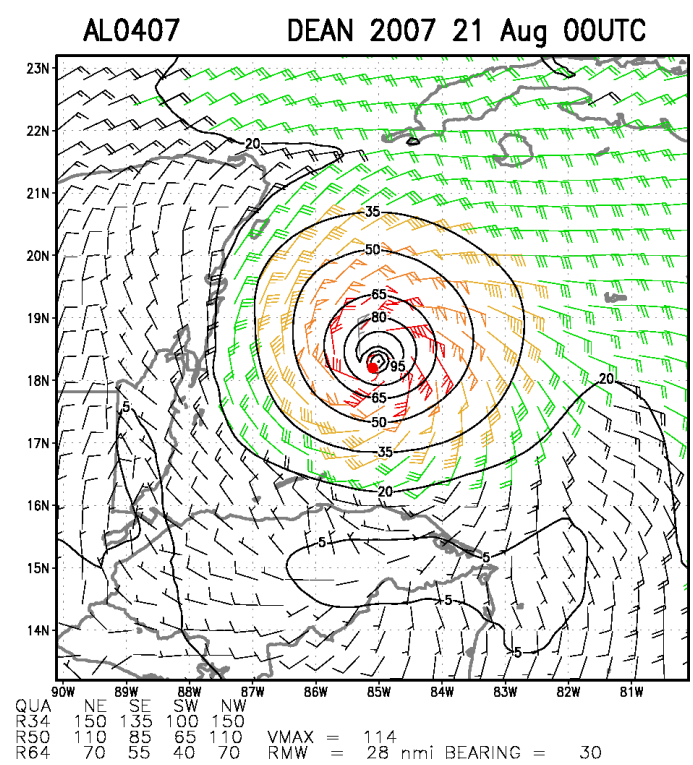

Figure 7 Real-time TC surface wind analysis during Hurricane Dean at 00UTC on 21 August 2007 (see https://rammbdata.cira.colostate.edu/tc realtime/image mpsatwnd.asp?product=mpsatwnd\&storm identifier=al042007\&product filename=2007al04 mpsatwnd 200708210000). 
Table 1 Met-ocean parameters measured at NDBC Buoy 42056 during Hurricane Dean in August 2007.

\begin{tabular}{|c|c|c|}
\hline Event & Reported Value & Date/Time of Event \\
\hline $\begin{array}{l}\text { Lowest } 1 \text { Minute Sea-Level Pressure } \\
\text { (MN1MSLP1) }\end{array}$ & $1000.5 \mathrm{hPa}$ & $08 / 202358 Z$ \\
\hline Maximum 10-minute Wind Speed (CWS) & $23.2 \mathrm{~m} / \mathrm{s}$ & $08 / 210030 Z$ \\
\hline Maximum 5-s Gust (MXGT1) & $32.1 \mathrm{~m} / \mathrm{s}$ & $08 / 202150 Z$ \\
\hline $\begin{array}{l}\text { Maximum one-minute Wind Speed } \\
(\mathrm{MX1MGT1)}\end{array}$ & $27.0 \mathrm{~m} / \mathrm{s}$ & $08 / 202250 Z$ \\
\hline Maximum Significant Wave Height (WVHGT) & $11.0 \mathrm{~m}$ & $08 / 210250 Z$ \\
\hline CPA Bearing and Distance to Hurricane & $191^{\circ} / 98.1 \mathrm{~nm}$ & 08/21 $0100 Z$ \\
\hline
\end{tabular}

By substituting these values into Eq. (1), one gets $U_{10}=61 \mathrm{kts}$ or $31 \mathrm{~m} \mathrm{~s}^{-1}$, which is in fair agreement with the 1-minute max value of $27 \mathrm{~m} \mathrm{~s}^{-1}$. As shown in Table 1, since there were about 2-hours difference between the measurements of $r$ and the 1-min $U_{10}$, Eq. (1) may be useful for estimating or nowcasting using RAMMB's output. Alternatively, for a rapid estimation of $U_{10}$, one can extrapolate it directly from the isotach (equal wind speed line) chart. For example, at Buoy 42056, located at $19.820 \mathrm{~N}$ and $84.945 \mathrm{~W}$, Figure 7 shows that, at 00 UTC on 21 Aug. 2007, $U_{10} \approx$ $55 \mathrm{kts}$ or $28 \mathrm{~m} \mathrm{~s}^{-1}$. This result is consistent with our estimated and measured values as discussed above.

\section{Estimating the Significant Wave Height, $\mathrm{H}_{s}$}

During a tropical cyclone at sea, according to [6, Eq. 3 (derived and verified using 5 TCs)],

$$
\mathrm{U}_{10}=2.2 \mathrm{H}_{\mathrm{s}}+5.3
$$

Here $U_{10}$ is the wind speed at $10-\mathrm{m}$ in $\mathrm{m} \mathrm{s}^{-1}$ and $H_{\mathrm{s}}$ is the significant wave height in meters.

On the basis of aforementioned 3 tropical cyclones, Eq. (2) is evaluated as follows: For Typhoon Soudelor, $U_{10}=72 \mathrm{~m} \mathrm{~s}^{-1}$ so $H_{\mathrm{s}}$ is nowcasted as $30 \mathrm{~m}$ vs. $28 \mathrm{~m}$ as measured; for Typhoon Krosa, $U_{10}=$ $57 \mathrm{~m} \mathrm{~s}^{-1}$ so $H_{\mathrm{s}}$ is estimated or nowcasted as $24 \mathrm{~m}$ vs. $24 \mathrm{~m}$ as measured; and For Hurricane Dean, $U_{10}=31 \mathrm{~m} \mathrm{~s}^{-1}$ so $H_{\mathrm{s}}$ is estimated or nowcasted as $12 \mathrm{~m}$ vs $11 \mathrm{~m}$ as measured (see Figure 6 and Table 1). Since the estimated or nowcasted $H_{s}$ values are in fair agreements with those measured, Eq. (2) may be used for nowcasting or estimation of $U_{10}$ from $H_{s}$ or vice versa.

\section{Estimating Overwater Friction Velocity, $\mathrm{U}_{*}$}

As stated in the Introduction, overwater friction velocity, $U_{*}$, is an essential link between the wind stress as the atmospheric forcing and the ocean response such as $H_{\mathrm{s}}$ and currents, $U_{\text {sea. }}$. Analysis of simultaneous measurements of $H_{s}$ and $U_{*}$ by direct eddy-correlation method based on [7, Table 1] and [8] is presented in Figure 8, indicating that

$$
U *=0.17 \mathrm{H}_{\mathrm{s}}
$$


With a correlation coefficient $R=0.73$.

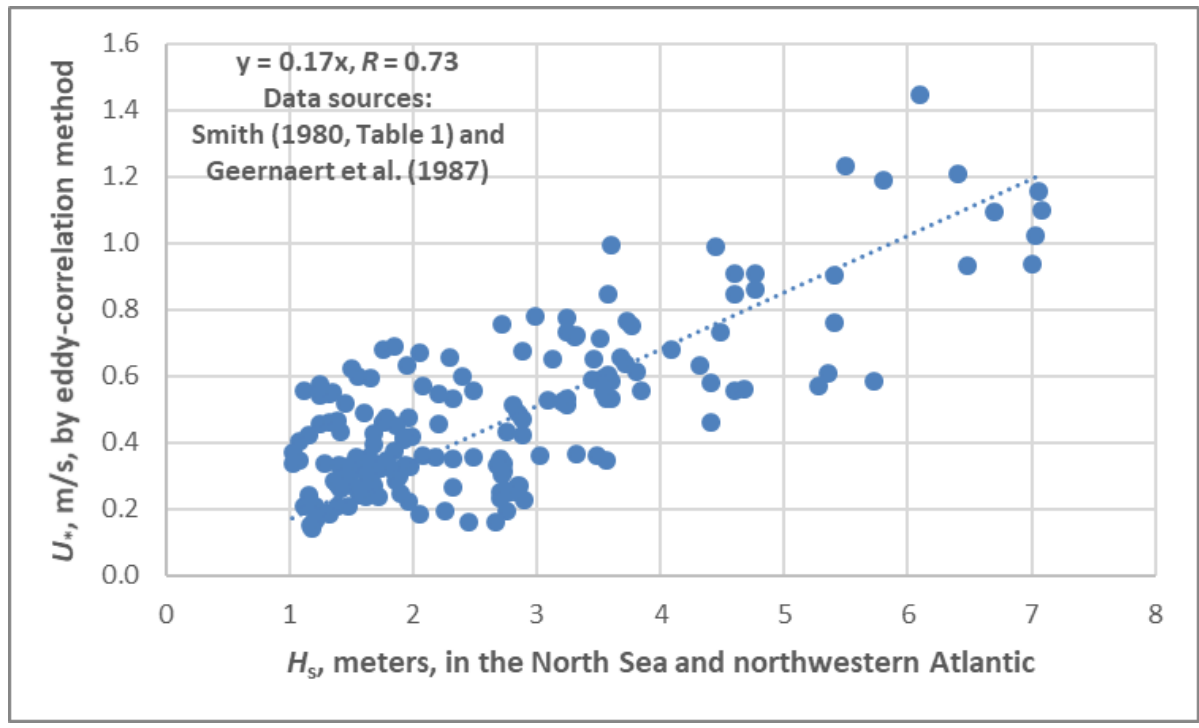

Figure 8 Relation between $\mathrm{U}^{*}$ and Hs based on direct measurements.

Note that, according to [9], the surface waves support most of the surface stress via form drag (normal stress) once the sea becomes fully rough, which occurs for wind speeds above approximately $7.5 \mathrm{~m} \mathrm{~s}^{-1}$. If we use $U_{10}$ as a surrogate for this wind speed, then, from Eq. (2), $H_{s}$ needs $\geq 1 \mathrm{~m}$. Therefore, the datasets used in Figure 8 are for the fully rough seas.

Figure 9 shows that Eq. (3) is verified by other independent method based on [10] at NDBC Buoy 42002 during Hurricane Delta in October 2020. According to [11, Eq. 4], $U *$ can also be estimated by $U_{\text {sea }}$ as follows:

$$
\mathrm{U}_{\text {sea }}=0.57 \mathrm{U} *
$$

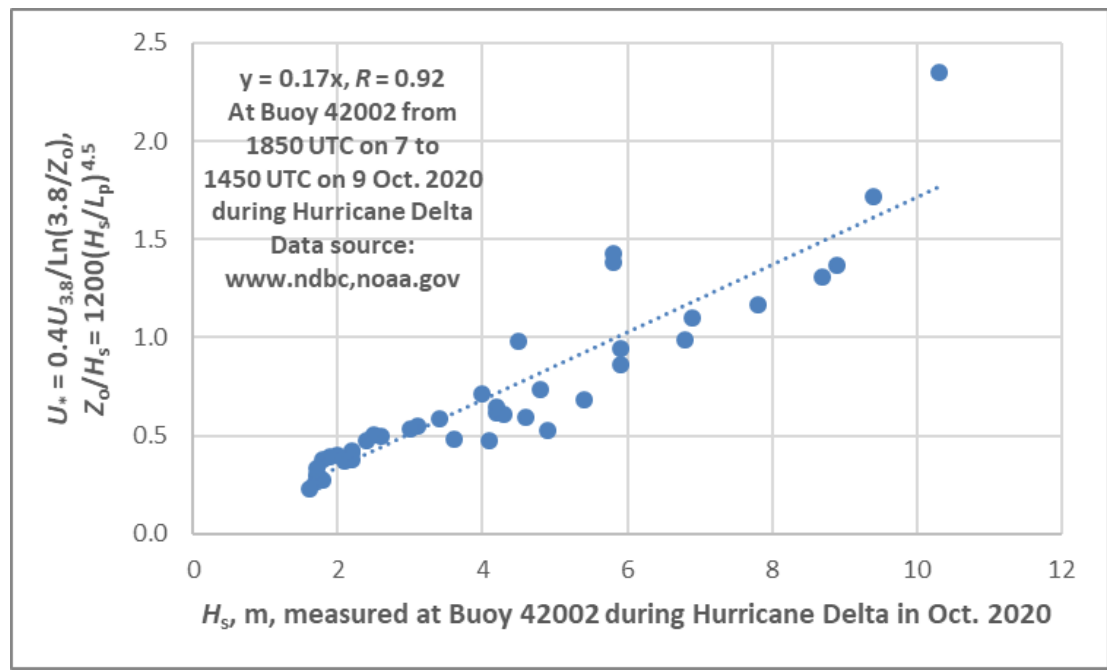

Figure 9 A verification of Eq. (3) during Hurricane Delta at NDBC Buoy 42002.

During Hurricane Ivan in 2004, an extreme value of Hs = 18 m was measured by [12, Tables 2 and 4]. From Table 2, Eq. (3) is validated. In addition, 


$$
\mathrm{U} *=30 \mathrm{H}_{\mathrm{s}}{ }^{2} / \mathrm{T}_{\mathrm{p}}{ }^{3}
$$

Here $T_{\mathrm{p}}$ is the peak or dominant wave period in seconds. Eq. (5) is verified in Figure 10 based on 3 major hurricanes [6]. According to [2, p. 68, Eq. 2.14]

$$
\mathrm{U} *=27.4 \mathrm{H}_{\mathrm{s}}{ }^{2} / \mathrm{T}_{\mathrm{p}}{ }^{3}
$$

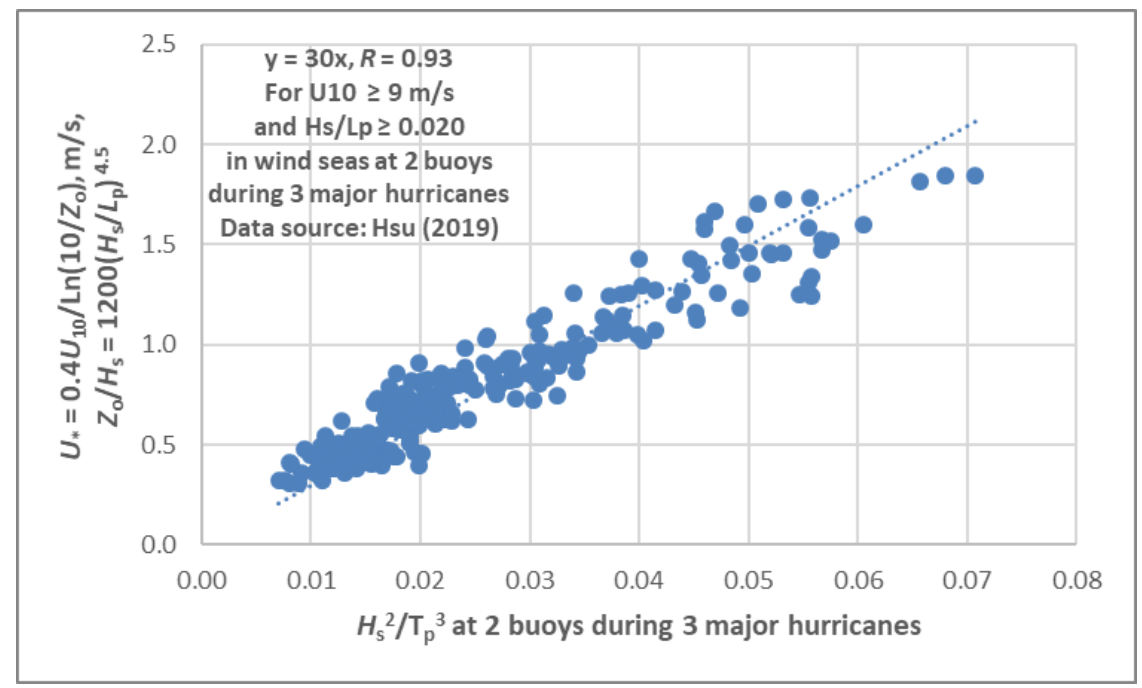

Figure 10 A verification of Eq. (5) during 3 major hurricanes.

Table 2 Measured and derived met-ocean parameters at Station M3 (for largest Hs) during Hurricane Ivan based on [12, Tables 2 and 4]. (Definitions of the parameters are given in the text).

\begin{tabular}{ccccccccc}
\hline$H_{\mathrm{s}}, \mathrm{m}$ & $T_{\mathrm{p}}, \mathrm{s}$ & $U_{\text {sea, }} \mathrm{m} / \mathrm{s}$ & $U_{10,} \mathrm{~m} / \mathrm{s}$ & $U_{*}, \mathrm{~m} / \mathrm{s}$ & $U_{*} /\left(H_{\mathrm{s}}{ }^{2} / T_{\mathrm{p}}{ }^{3}\right)$ & $U_{*} / H_{\mathrm{s}}$ & $U_{\text {sea }} / H_{\mathrm{s}}$ & $U_{\text {sea }} / U_{*}$ \\
\hline 18.0 & 14.8 & 1.73 & 45 & 3.0 & 30 & 0.17 & 0.10 & 0.57 \\
\hline
\end{tabular}

Since the difference between Equations (5) and (6) is $8.7 \%$, our approach is reasonable. Note that Eq. (5) is obtained under 3 major hurricanes as illustrated in Figure 10. However, since the value of Tp is not always available, Eq. (3) is recommended for nowcasting.

\section{Estimating the Wind Speed Variation with Height}

According to [13, p. 112], under near-neutral stability conditions such as during a TC [14],

$$
\mathrm{U}_{2}-\mathrm{U}_{1}=2.5 \mathrm{U} * \ln \left(\mathrm{Z}_{2} / \mathrm{Z}_{1}\right)
$$

Here $U_{2}$ and $U_{1}$ are the wind speeds at heights $Z_{2}$ and $Z_{1}$, respectively, for estimating wind speed change vertically.

Eq. (7) is validated as follows: during Hurricane Ivan in September 2004, according to the National Hurricane Center (NHC) [15] (https://www.nhc.noaa.gov/data/tcr/AL092004 Ivan.pdf), an anemometer at $400 \mathrm{ft}$ (122 m) elevation at Ram Powell VK-956 Oil Rig located at 29.05N and 88.10W recorded the wind speed at $102 \mathrm{kts}(52.6 \mathrm{~m} / \mathrm{s})$ at 2256 UTC on 15 September. The same report states 
that, nearly at the same time in the vicinity of said oil platform, the National Data Buoy Center (NDBC) Buoy 42040 located at $29.2 \mathrm{~N}$ and $88.2 \mathrm{~W}$ measured a $55 \mathrm{kts}(28.4 \mathrm{~m} / \mathrm{s})$ at $5 \mathrm{~m}$ height. During this period, according to Teague et al. ([12], Figure 1 and Table 3) [12], the largest $H_{\mathrm{s}}=18 \mathrm{~m}$ (see Table 2) was measured at Station M3. Therefore, by substituting the $H_{s}$ value into Eq. (3), we have $U_{*}=$ $3.06 \mathrm{~m} \mathrm{~s}^{-1}$. Now setting $Z_{1}=5 \mathrm{~m}$ and $Z_{2}=122 \mathrm{~m}$, the right-hand side of (7) is $24 \mathrm{~m} \mathrm{~s}^{-1}$. Since the difference in wind speed between $Z_{1}$ and $Z_{2}$ is also $24 \mathrm{~m} \mathrm{~s}^{-1}$, Eq. (7) is recommended for nowcasting.

Another validation of Eq. (7) is provided as follows: from Eq. (7), by setting $U_{1}=U_{10}$ and $Z_{1}=10 \mathrm{~m}$ and from Eq. (3), we have

$$
\mathrm{U}_{\mathrm{z}}=\mathrm{U}_{10}+0.43 \mathrm{H}_{\mathrm{s}} \ln (\mathrm{Z} / 10)
$$

Here $U_{z}$ is for the wind speed at height $Z$. According to the National Hurricane Center (https://www.nhc.noaa.gov/archive/2020/ZETA.shtml?) and the National Data Buoy Center (see https://www.ndbc.noaa.gov/station page.php?station=lopl1), the Louisiana Offshore Oil Port (LOPL1) was impacted by Hurricane Zeta. At 2133 UTC on 28 Oct. 2020, $H_{\mathrm{s}}=7.92 \mathrm{~m}$ was measured at LOPL1. Substituting this $H_{\mathrm{s}}$ value into Eq. (2), we have $U_{10}=22.7 \mathrm{~m} \mathrm{~s}^{-1}$ and into Eq. (3), $U_{*}=1.35$ $\mathrm{m} \mathrm{s}^{-1}$. Since the anemometer was located at $Z=57.9 \mathrm{~m}$ and by substituting the values of $U_{10}, U_{*}$ and $Z$ into Eq. (8), one gets $U_{57.9}=28.7 \mathrm{~m} \mathrm{~s}^{-1}$. Comparison of this estimate value against that of $27.2 \mathrm{~m} \mathrm{~s}$ ${ }^{-1}$ as measured at $57.9 \mathrm{~m}$ at 1958 UTC on 28 Oct. 2020 on the platform of LOPL1 indicates that Eq. (8) may be used for nowcasting, since the difference between the estimated and measured is about $5 \%$. Note also there was about 1.5 hours difference between the measurements of $H_{s}$ and $U_{57.9}$.

\section{Estimating the Wind-Driven Currents}

From Eqs. (3) and (4), we have

$$
U_{\text {sea }}=0.10 H_{s}
$$

Eq. (9) is validated in Table 2. As stated in the Introduction, during Typhoon Krosa, an extreme $\mathrm{Hs}=23.9 \mathrm{~m}$ as measured off the northeastern coast of Taiwan should have generated an extreme value of Usea $=0.10 * 23.9=2.39 \mathrm{~m} \mathrm{~s}^{-1}$ or about $4.6 \mathrm{kts}$.

\section{Estimating the Wind-stress Tides}

During a TC, according to [16], the most important natural hazard is the wind-stress tide, $S_{\text {wind, }}$ (which is defined as the water level rise balanced by the wind stress above the normal astronomical tide) and from Eq. (3), we have

$$
\mathrm{S}_{\text {wind }}=\tau=\rho U *^{2}=1.22\left(0.17 \mathrm{H}_{\mathrm{s}}\right)^{2}=0.035 \mathrm{H}_{\mathrm{s}}^{2}
$$

Here $\tau$ and $\rho$ are the wind stress and air density for the moist air, respectively. All units are in SI.

Verification of Eq. (10) is presented as follows: During Hurricane Katrina in 2005, according to [17], by substituting the largest $H s=16.91 \mathrm{~m}$ as measured at Buoy 42040 in deep water into Eq. (10), we have the highest $S_{\text {wind }}=10 \mathrm{~m}$. Since this estimated value is identical to that of $33 \mathrm{ft}$ or $10 \mathrm{~m}$ as measured at Station KMSC, Eq. (10) is validated. 
Application of Eq. (10) using RAMMB's product is provided as follows: During Hurricane Michael in 2018, Figure 11 shows that, just before its landfall on the northwest coast near Mexico beach, Florida, there were approximately $70 \mathrm{kts}$ or $35 \mathrm{~m} \mathrm{~s}^{-1}$ wind speeds directly perpendicular to the shoreline. By substituting this wind speed into Eq. (2), $H_{\mathrm{s}}=13.5 \mathrm{~m}$. Now, substituting this $H_{\mathrm{s}}$ value into Eq. (10), the wind stress tide can be nowcasted quickly at $6.4 \mathrm{~m}$. Since this nowcasted value is in excellent agreement with that of measured $6.3 \mathrm{~m}$ as illustrated in Figure 12, Eq. (10) can be used for nowcasting the wind-stress tide, which is the most important component in the total storm surge estimation.

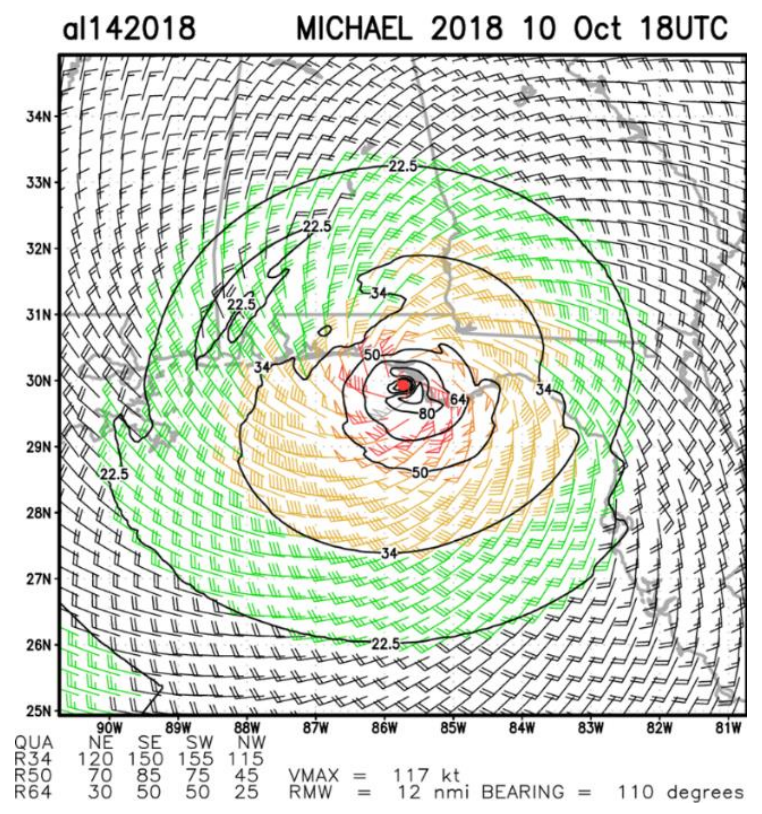

Figure 11 RAMMB's surface wind analysis for 18 UTC on 10 Oct 2018 during Hurricane Michael just before its landfall near Mexico Beach, Florida based on RAMMB: TC RealTime: AL142018 - Major Hurricane MICHAEL - Aircraft-based Tropical Cyclone Surface Wind Analysis (colostate.edu).

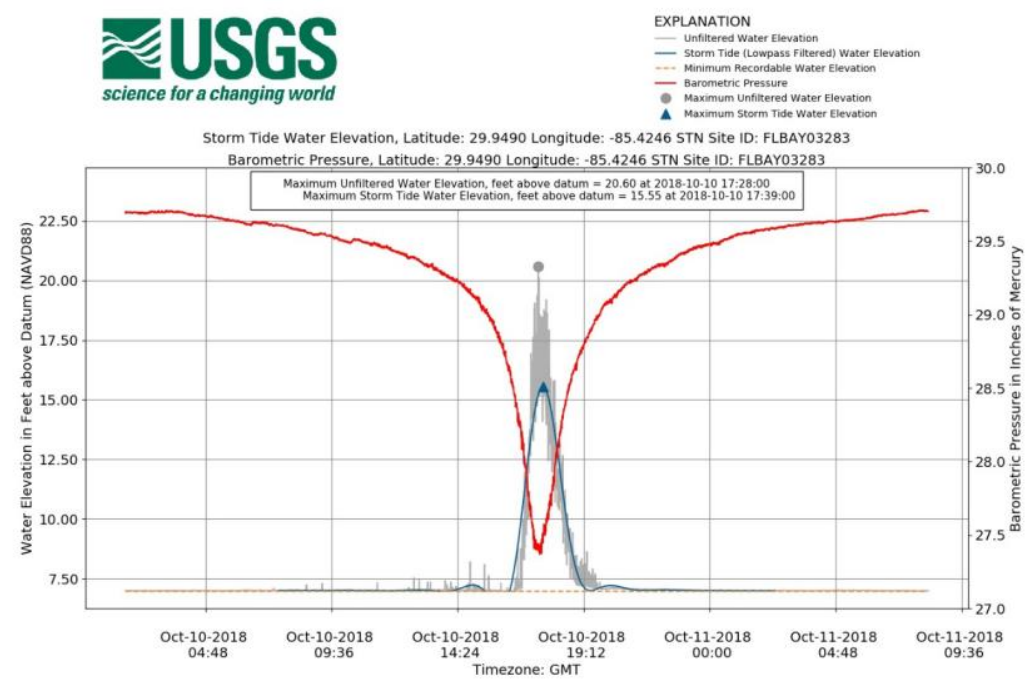

Figure 12 Maximum unfiltered water elevation of $20.6 \mathrm{ft}$ or $6.3 \mathrm{~m}$ was measured near the time shown in Figure 11 during Hurricane Michael based on the U. S. Geological 
Survey (USGS) at [18] Monitoring Storm Tide from Hurricane Michael Along the Northwest Coast of Florida, October 2018 (usgs.gov).

\section{Estimating the Peak Wave Period, $T_{\mathrm{p}}$}

If the peak or dominant wave period, $T_{\mathrm{p}}$, is not available, according to [6, Eq. 2 which was also verified by 3 hurricanes as shown in (6, Table 1 and Figure 3)], it may be estimated from $H_{s}$ in deep water that,

$$
\mathrm{T}_{\mathrm{p}}=\mathrm{H}_{\mathrm{s}} /(0.062 \mathrm{Hs}+0.15)
$$

\section{Estimating the Variation of $\boldsymbol{H}_{\mathrm{s}}$ from Deep to Shallow Water}

Using the measured or estimated deep-water value of $T_{\mathrm{p}}$ as discussed in the last Section, the variation of $H_{s}$ from deep to shallow water may be nowcasted. This is based on the following facts: On 3 September 2019, when the center of Hurricane Dorian was located south of a buoy network consisting of 41010, 41009 and 41113 off the East Coast of Florida (for locations, see https://www.ndbc.noaa.gov/maps/Florida.shtml), the onshore variation of the significant wave height, $H_{s}$, from deep to shallow water was measured. The datasets are listed in Table 3 . Analysis of these datasets is shown in Figure 13, indicating that, during wind seas in deep water when wave steepness, $H_{s} / L_{p} \geq 0.020[10]$,

$$
\mathrm{H}_{\mathrm{s}} / \mathrm{H}_{\mathrm{so}}=0.9781\left(\mathrm{D} / \mathrm{D}_{\mathrm{s}}\right)^{0.6714}
$$

With a very high coefficient of determination, $R^{2}=0.9984$.

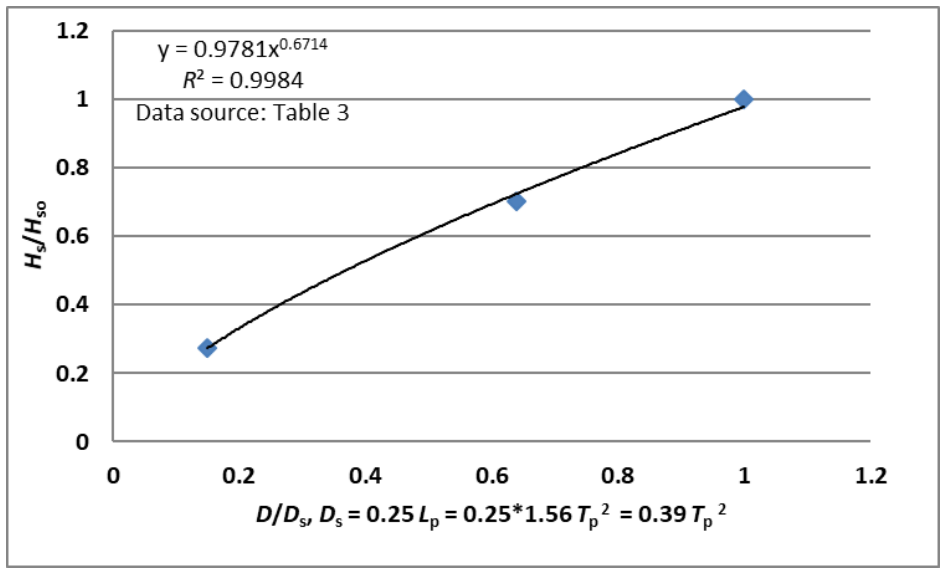

Figure 13 Relation between dimensionless wave height and water depth based on Table 3.

Table 3 Nearly simultaneous real-time measurements of large waves at three buoys off the East Coast of Florida on September 3 in 2019 during Hurricane Dorian (Data source: www.ndbc.noaa.gov and https://www.ndbc.noaa.gov/maps/Florida.shtml).

\begin{tabular}{lllllllll}
\hline Buoy & Time, & $D=$ water & $H_{\mathrm{s}}$ & $T_{\mathrm{p},}$ & $D_{\mathrm{s}}=$ shoaling & $D / D_{\mathrm{s}}$ & $H_{\mathrm{s}} / H_{\mathrm{so}}$ \\
& UTC & depth, $\mathrm{m}$ & meters & seconds & Depth, $\mathrm{m}$ & & & \\
\hline
\end{tabular}




\begin{tabular}{llllllll}
\hline 41010 & 2350 & 890 & 9.8 & 13 & $890^{*}$ & 1.0 & 1.0 \\
41009 & 2250 & 42 & 6.9 & 13 & 66 & 0.64 & 0.70 \\
41113 & 2300 & 9.8 & 2.7 & 13 & 66 & 0.15 & 0.28 \\
\hline
\end{tabular}

* For reference depth without shoaling waves.

Here $H_{\mathrm{s}}$ and $H_{\mathrm{so}}$ are the significant wave heights after and before wave shoaling, respectively, $D$ is the water depth for shallow water, and $D_{s}$ represents the shoaling depth $\left(=0.25 L_{p}=0.25 * 1.56\right.$ $T_{\mathrm{p}}{ }^{2}=0.39 T_{\mathrm{p}}{ }^{2}$, where $L_{\mathrm{p}}$ is the dominant wave length and $T_{\mathrm{p}}$ is the dominant wave period, see, e.g. [19]).

On 29 August 2005, Buoys 42040 and 42007 in the north central Gulf of Mexico, both located on the right-hand side of the track of Hurricane Katrina (see [20] https://www.ndbc.noaa.gov/hurricanes/2005/katrina/). The largest $H_{\mathrm{s}}$ for each station is listed in Table 4. Based on Eq. (12), we have $H_{\mathrm{s}}=16.91 * 0.9781^{*}(14.9 / 79.6)^{0.6714}=5.4 \mathrm{~m}$. This result is in reasonable agreement with that of $5.6 \mathrm{~m}$ as measured at 42007 (see Table 4).

Table 4 Buoy measurements of the largest Hs at 42040 and 42007 on the right-hand side of Hurricane Katrina track on August 29 in 2005 (Data source: [20] https://www.ndbc.noaa.gov/hurricanes/2005/katrina/).

\begin{tabular}{cccccc}
\hline Buoy & Time, UTC & Water depth, $\mathrm{m}$ & $H_{\mathrm{s}}, \mathrm{m}$ & $T_{\mathrm{p}}$, second & $D_{\mathrm{s}, \mathrm{m}}$ \\
\hline 42040 & 1100 & 183 & 16.91 & 14.29 & 79.6 \\
42007 & 0500 & 14.9 & 5.64 & 14.29 & 79.6 \\
\hline
\end{tabular}

Another application of Eq. (12) is for rapid estimation of $H_{\mathrm{s}}$ within the shoaling wave region. This is done by the following:

For location 1, we have

$$
\mathrm{H}_{\mathrm{s} 1} / \mathrm{H}_{\mathrm{so}}=0.9781\left(\mathrm{D}_{1} / \mathrm{D}_{S}\right)^{0.6714}
$$

And for location 2,

$$
\mathrm{H}_{\mathrm{s} 2} / \mathrm{H}_{\mathrm{so}}=0.9781\left(\mathrm{D}_{2} / \mathrm{D}_{s}\right)^{0.6714}
$$

Now, by dividing Equations (13) and (14), one gets

$$
\mathrm{H}_{\mathrm{s} 1} / \mathrm{H}_{\mathrm{s} 2}=\left(\mathrm{D}_{1} / \mathrm{D}_{2}\right)^{0.6714}
$$

On 5 September 2019 during Hurricane Dorian, two buoys within the shoaling wave environment, 41013 and 41108 off the North Carolina coast (for locations see www.ndbc.noaa.gov) measured $\mathrm{H}_{\mathrm{s}}$ and $T_{\mathrm{p}}$ as provided in Table 5. Based on Eq. (15), we have $H_{\mathrm{s} 1} / H_{\mathrm{s} 2}=6.87 / 4.64=1.48$ for the lefthand side of Eq. (14) and $\left(D_{1} / D_{2}\right)^{0.6714}=(23.5 / 12.8)^{0.6714}=1.50$ for the right. Since the difference is negligible, it is concluded that Eq. (12) is a useful formula for a rapid estimation of the variation in significant wave height from deep to shallow water environments when the wind waves propagate in the onshore direction. 
Table 5 Nearly simultaneous measurements of large waves in the shallow waters at two buoys off the North Carolina Coast on September 5 in 2019 during Hurricane Dorian (Data source: www.ndbc.noaa.gov).

\begin{tabular}{cccccc}
\hline Buoy & Time, UTC & Water Depth, $\mathrm{m}$ & $H_{\mathrm{s}}, \mathrm{m}$ & $T_{\mathrm{p}}$, second & Wave direction \\
\hline 41013 & 2240 & 23.5 & 6.87 & 11.43 & 180 \\
41108 & 2230 & 12.8 & 4.64 & 11.76 & 178 \\
\hline
\end{tabular}

\section{Estimating Overwater Turbulence Intensity}

Knowledge of overwater turbulence intensity $(\mathrm{TI})$ at the wind-turbine hub height is essential for offshore wind-power research, development, operation and maintenance. According to [14, 21], TI at height $Z$ may be written as

$$
\mathrm{TI}_{\mathrm{z}}=2.5 \mathrm{U} * / \mathrm{U}_{\mathrm{z}}=1 / \mathrm{Ln}\left(\mathrm{Z} / \mathrm{Z}_{O}\right)
$$

and following [19],

$$
\mathrm{Z}_{O}=1200 \mathrm{H}_{\mathrm{s}}\left(\mathrm{H}_{\mathrm{s}} / L_{p}\right)^{4.5}
$$

Here $Z_{o}$ is the aerodynamic roughness length in $m$ and the parameter $H_{s} / L_{p}$ is the wave steepness.

Now, if a wind farm is situated in deep water environment or there is no wave shoaling problem, one may use the values of $U_{*}$ and $U_{z}$ as nowcasted from Equations (3) and (8), respectively, to estimate $\mathrm{TI}_{z}$. However, because of the construction coast most wind farms are designed for shallower waters where most waves are the results of shoaling during storms. Therefore, Eq. (17) may be more suitable. An example for the characteristics of shoaling waves is further investigated as follows: When Hurricane Sally in September 2020 (for its track, see www.nhc.noaa.gov) was over the northeastern Gulf of Mexico, Buoy 42012 (for its location see www.ndbc.noaa.gov) located at the water depth of $25.9 \mathrm{~m}$ was under extensive shoaling wave conditions. Note that, as discussed in the last section, at the water depth of this buoy, shoaling wave condition prevailed when the peak wave period, $T p \geq 8$ seconds. Using this criterion, analysis of these shoaling waves for the relation between wave steepness and significant wave height is presented in Figure 14, indicating that

$$
\mathrm{H}_{\mathrm{s}} / L_{p}=0.0065 \mathrm{H}_{\mathrm{s}}
$$

With $R=0.90$. Therefore, using Equations (16) thru (18), overwater turbulence intensity may be estimated as a first approximation if in-situ measurements of TI are not available. 


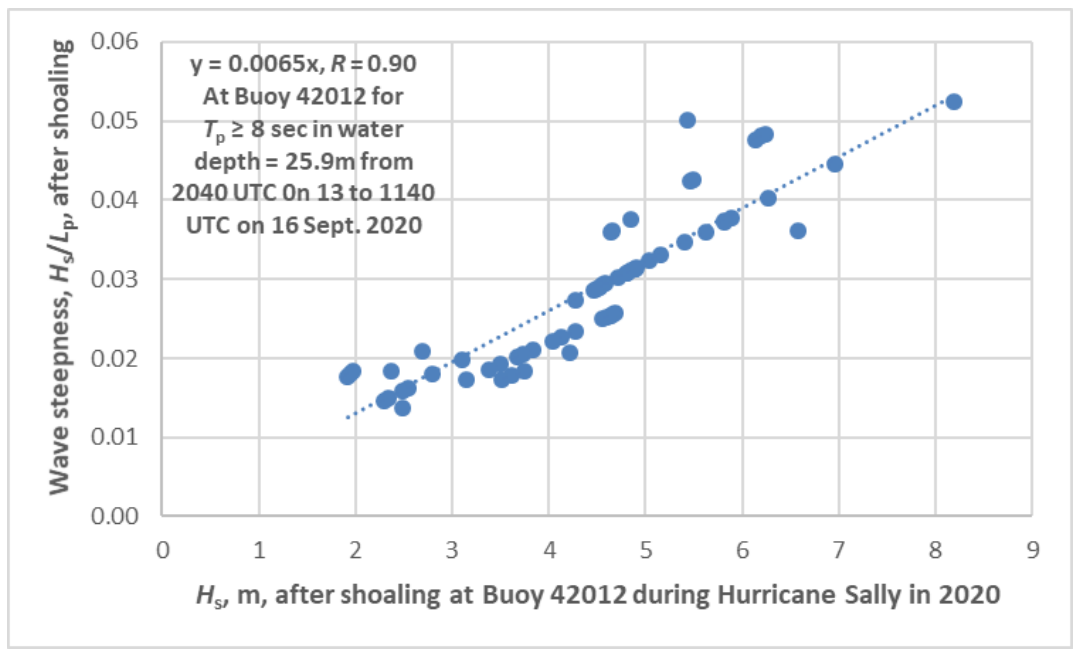

Figure 14 Relation between wave steepness and significant wave height at Buoy 42012 under shoaling wave conditions during Hurricane Sally in 2020.

\section{Conclusions}

Based on above analyses and discussions, it is concluded that

(1) Estimating the wind speed at $10-\mathrm{m}, U_{10}$, may be made by using Eq. (1) from the known distance between the storm center and the site in question using the VMAX and RMW values as provided in RAMMB Real-time TC surface wind analysis. Alternatively, one can extrapolate the isotach chart or the wind data from the grid closest to the site;

(2) Estimating the significant wave height, $H_{s}$, may be made by using Eq. (2);

(3) Estimating overwater friction velocity, $U_{*}$, may be made by using Eq. (3);

(4) Estimating the wind speed variation with height may be made by using Eq. (8);

(5) Estimating the wind-driven currents may be made by using Eq. (9);

(6) Estimating the wind-stress tides may be made by using Eq. (10);

(7) Estimating the peak wave period may be made by using Eq. (11);

(8) Estimating the $H_{s}$ variation from deep to shallow water or vice versa, using Eq. (12); and finally

(9) Estimating overwater turbulence intensity may be made by using Equations (16) thru (18).

Certainly, formulas as proposed in this study may be improved as more validations become available.

\section{Acknowledgments}

Appreciations go to RAMMB, NDBC and USGS, for providing the information used in this study.

\section{Author Contributions}

The author did all the research work of this study.

\section{Competing Interests}

The author has declared that no competing interests exist. 


\section{References}

1. Bancroft GP. Marine weather review - North Pacific Area. March to August 2015. Mar Weather Log. 2016; $60 . \quad$ Available from: http://www.vos.noaa.gov/MWL/201604/northpacific.shtml\#contents.

2. Csanady GT. Air-sea interaction: Laws and mechanisms. Cambridge, England: Cambridge University Press; 2001.

3. Babanin AV, Hsu TW, Roland A, Ou SH, Doong DJ, Kao CC. Spectral wave modelling of Typhoon Krosa. Nat Hazards Earth Syst Sci. 2011; 11: 501-511.

4. Anthes RA. Tropical cyclones: Their evolution, structure and effects. Boston, Massachusetts, US: American Meteorological Society; 1982.

5. Reports from the National Data Buoy Center's stations during the passage of Hurricane Dean. 13-23 August 2007 [Internet]. National Data Buoy Center. Available from: https://www.ndbc.noaa.gov/hurricanes/2007/dean/.

6. Hsu SA. A practical formula relating wind speed and significant wave height during tropical cyclones. Mar Weather Log. 2019; 63: 25-28.

7. Smith SD. Wind stress and heat flux over the ocean in gale forth wind. J Phys Oceanogr. 1980; 10: 709-726.

8. Geernaert GL, Larsen SE, Hansen F. Measurements of the wind stress, heat flux, and turbulence intensity during storm conditions over the North Sea. J Geophys Res. 1987; 92: 13127-13139.

9. Donelan MA. Air-sea interaction. In: Ocean engineering science. Hoboken, New Jersey: Wiley; 1990.

10. Hsu SA, He Y, Shen S. Buoy measurements of wind-wave relations during Hurricane Matthew in 2016. J Phys Oceanogr. 2017; 47: 2603-2609.

11. Wu J. Sea-surface drift currents induced by wind and waves. J Phys Oceanogr. 1983; 13: 14411451.

12. Teague WJ, Jarosz E, Wang DB, Mitchell DA. Observed oceanic response over the upper continental slope and outer shelf during Hurricane Ivan. J Phys Oceanogr. 2007; 37: 2181-2206.

13. Hsu SA. Coastal meteorology. Cambridge, Massachusetts: Academic Press; 1988.

14. Hsu SA. Estimating overwater friction velocity and exponent of power-law wind profile from gust factor during storms. J Waterw Port Coast Ocean Eng. 2003; 129: 174-177.

15. Stewart SR. Tropical Cyclone Report. Hurricane Ivan. 2-24September 2004 [Internet]. Available from: https://www.nhc.noaa.gov/data/tcr/AL092004 Ivan.pdf.

16. Hsu SA. Storm surge in New York during Hurricane Sandy in 2012: A verification of the windstress tide relation. Boundary Layer Meteorol. 2013; 148: 593-598.

17. Hsu SA, Liu B. Wave setup during Hurricane Katrina and Tropical Cyclone Mahina. Mar Weather Log. 2014; 58. Available from https://www.vos.noaa.gov/MWL/201412/cyclones.shtml.

18. Byrne MJ. Monitoring storm tide from Hurricane Michael along the Northwest Coast of Florida, October 2018 [Internet]. U.S. Department of the Interior. U.S. Geological Survey. Available from: https://pubs.usgs.gov/of/2019/1059/ofr20191059.pdf.

19. Taylor PK, Yelland MJ. The dependence of sea surface roughness on the height and steepness of the waves. J Phys Oceanogr. 2001; 31: 572-590.

20. Reports from the National Data Buoy Center's stations in the Gulf of Mexico during the passage of Hurricane Katrina. 27-30 August 2005 [Internet]. National Data Buoy Center. Available from: 
https://www.ndbc.noaa.gov/hurricanes/2005/katrina/.

21. Hsu SA, Blanchard BW. Estimating overwater turbulence intensity from routine gust-factor measurements. J Appl Meteorol Climatol. 2004; 43: 1911-1916.

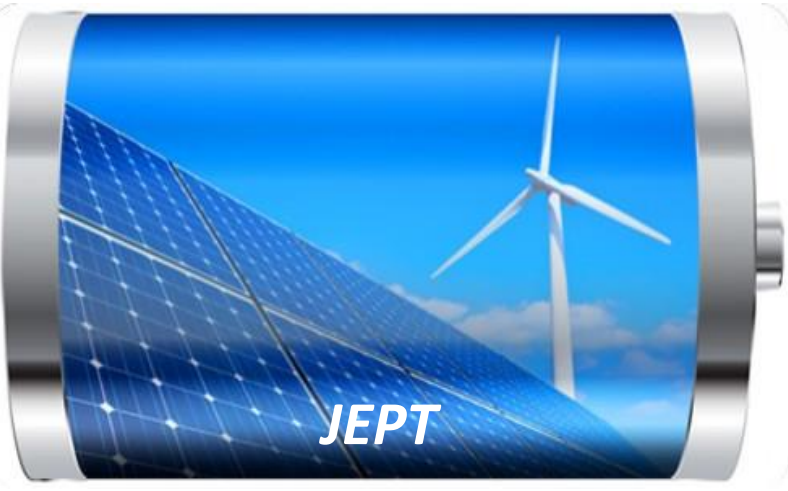

Enjoy JEPT by:

1. Submitting a manuscript

2. Joining in volunteer reviewer bank

3. Joining Editorial Board

4. Guest editing a special issue

For more details, please visit:

http://www.lidsen.com/journal/jept 